\title{
PERENCANAAN DAN STRATEGI KOMUNIKASI DALAM MENINGKATKAN ADAPTIFITAS SUMBERDAYA MANUSIA DAN KEUNGGULAN KOMPETITIF LEMBAGA
}

\author{
Iswahyu Pranawukir \\ Institut Bisnis dan Informatika Kosgoro 1957 Jakarta, Indonesia \\ prana1enator@gmail.com
}

\begin{abstract}
Planning and communication strategies are one of the keys in increasing adaptability in an institution or organization, including Islamic boarding schools. The purpose of this study is to determine the planning and communication strategies in increasing the adaptability of human resources and competitiveness of the Madinatul Qur'an Islamic boarding school in Depok. Through qualitative descriptive method, the results of planning and communication strategies are obtained according to the stages. The planning stage is to formulate the scientific, capacity and character building. The strategy formulation stage produces an aggressive strategy, involving HR target as partners with various stimuly, refresher strategy through social service practices, growth strategy through the development of intellectual, religious, humanist and adaptive character; defensive strategies through interdisciplinary and transdisciplinary training. Furthermore, the stages of personal competence, through improving communication, managerial and business skills, control stages that focus on the uniqueness of tahfidz, the supervision stage, in the form of optimizing the role of HR and the evaluation stage, in order to encourage the sensitivity of HR to technological developments. Lastly is the communication strategy stage. The graduates of Ma'had Aly will be facilitated with a bachelor degree In order to fulfill the stakeholders' demand.
\end{abstract}

Keywords: communication strategy, communication planning, adaptive HR, institutional competitive.

\begin{abstract}
Abstrak
Perencanaan dan strategi komunikasi menjadi salah satu kunci dalam meningkatkan adaptifitas di sebuah Lembaga atau organisasi termasuk pondok pesantren. Tujuan penelitian untuk mengetahui perencanaan dan strategi komunikasi dalam meningkatkan adaptifitas sumberdaya manusia dan kompetitif lembaga pondok pesantren Madinatul Qur'an Depok. Melalui metode deskriptif kualitatif, didapatkan hasil perencanaan dan strategi komunikasi berdasarkan perencanaan tahapan-tahapan pada komunikasi organisasi dan pada pelibatan sumber daya manusia. Tahapan perencanaan dengan merumuskan scientific building, capacity and character building. Tahapan perumusan strategi, menghasilkan strategi agresif, yakni pelibatan SDM sasaran sebagai partner dengan berbagai stimulusnya; strategi penyegaran melalui praktik pengabdian sosial kemasyarakatan; strategi pertumbuhan melalui pembangunan karakter intelek, religius, humanis dan adaptif; strategi defensif melalui pelatihan interdisiplin dan transdisiplin. Selanjutnya, tahapan kompetensi personal, melalui peningkatan kemampuan komunikasi, manajerial dan perbisnisan, tahapan pengendalian yang memusatkan kekhasan tahfidz; tahapan pengawasan, berupa optimalisasi peran SDM dan tahapan pengevaluasian, demi mendorong kepekaan SDM terhadap perkembangan teknologi. Terakhir adalah strategi komunikasi yang dilancarkan, yakni lulusan Ma'had Aly akan difasilitasi jenjang pendidikan formal (sarjana) demi memenuhi tuntutan stakeholders.
\end{abstract}

Kata Kunci: strategi komunikasi; perencanaan komunikasi; sdm adaptif; kompetitif lembaga

\section{PENDAHULUAN}

Manusia merupakan inti kapital, sehingga muncul istilah human capital. Oleh karena itu, pencapaian kompetitif suatu lembaga atau organisasi dari aspek manusia (human) menjadi sangat tidak terelakkan. Pemikiran ini 
kemudian menjadi cikal bakal tumbuhnya manajemen sumberdaya. Terminologi dari fenomena ini adalah bidang yang sangat populer didalam dunia manajemen, yakni aspek manajemen strategis yang paling mungkin untuk terus ditingkatkan adalah sumberdaya manusianya.

Manajemen strategis menitikberatkan pada human capital dalam suatu organisasi yang menekankan pengertian bahwa manusia merupakan salah satu modal utama untuk pengoperasian jalannya organisasi itu sendiri guna menghasilkan nilai atau menambah nilai serta jumlah yang tak terbatas dan tidak terhingga. Hasil akhir yang ingin dicapai adalah value added bagi stakeholder sebagai pihak pemangku kepentingan, seperti: mahasiswa/peserta didik, orangtua, lembaga pendidikan lain, pengelola profesi pendidikan, masyarakat, serta siapapun yang memiliki kepentingan dari sebuah usaha dalam organisasi tersebut (Prasojo, Mukminin, Mahmudah, 2017) dan (Karnati, 2019).

Selanjutnya, pengembangan MSDM (manajemen sumberdaya manusia) kemudian dipahami dalam konteks "pengelolaan" yang berarti human sebagai kapital yang wajib dikelola. Dengan demikian, MSDM sebagai sumber bagi kemajuan organisasi jenis apapun yang berkaitan dengan sebuah proses, yakni proses strategis pengelolaan sumberdaya manusia.(Hasibuan, 2016)

Dalam perkembangan terakhir, kemajuan pendidikan Islam sangatlah pesat hal ini ditandai dengan datangnya era reformasi dan globalisasi ternyata justru memperkuat paradigma sumberdaya manusia yang menuntut beragam kualitas. Oleh karenanya diperlukan upaya-upaya untuk meningkatkan adaptifitas sumber daya demi keunggulan kompetitif pada nilai-nilai keagamaan dalam setiap aktivitasnya. Aktivitas yang dimaksud sangatlah mengarah ke paradigma daya survive (bertahan) suatu struktur organisasi pada pondok pesantren.

Modernisasi pesantren adalah dimaknai kepada strukur atau sistem organisasi pesantren yang berusaha mengintegrasikan setiap fungsi- fungsi komunikasi yang memasuki sistem klasikal dan sekolah/ madrasah kedalam pondok pesantren. Santri dibagi secara berkelas, berjenjang atau bertingkat, menggunakan lokal, kursi dan papan tulis, kurikulum dalam bentuk pengajian klasik tidak lagi menonjol, sistem sorogan dan bandungan sudah berubah menjadi individual dalam hal belajar dan kuliah.

Dari keterangan diatas, sehingga dapat dipahami dengan lugas bahwa unit dasar fungsi organisasi adalah seseseorang antar hubungan komunikasi dalam jabatan-jabatan. Mengingat komunikasi di dalam sebuah organisasi merupakan sesuatu yang penting, diperlukan sebuah strategi atau langkah cerdik yang harus dilakukan oleh suatu organisasi dalam meningkatkan sumber daya dan keunggulan kompetitif. Dengan demikian suatu organisasi adalah terdiri dari unit-unit komunikasi dalam hubungan hierarkis antara yang satu dengan yang lainnya dan berfungsi dalam suatu lingkungan (Mahanani \& Christanti, 2020). Demikian pula pada organisasi Pesantren yang dimaksud jabatan disini yaitu memandang terbentuknya komponen dalam sistem organisasi ialah hierarki, saling ketergantungan dan saling terbuka diantara para santri.

Secara umum, tipe organisasi pada pesantren sudah berbentuk khalafi, maksudnya sudah menerima hal-hal baru yang dinilai lebih baik di samping tetap mempertahankan tradisi lama. Dalam modernisasi pendidikan Islam dan perubahan-perubahan sosial ekonomi yang berlangsung dalam masyarakat Indonesia sejak awal abad ini mencakup: pertama, pembaruan substansi atau isi pendidikan pesantren dengan memasukkan subyek-subyek umum dan vocational; kedua, pembaruan metodologi, seperti sistem klasikal, penjenjangan; ketiga, pembaruan kelembagaan, seperti kepemimpinan pesantren, diversifikasi lembaga pendidikan; dan keempat, pembaruan fungsi, dari semula hanya fungsi kependidikan, dikembangkan sehingga juga mencakup fungsi sosial-ekonomi. (Muammar, 2017).

Inilah suguhan tantangan sekaligus tuntutan pondok pesantren sebagai lembaga 
pendidikan non-mainstream yang mampu menjawab keunggulan kompetitif di era perubahan zaman. Keunggulan kompetitif memang menjadi isu yang disampaikan Bapak Direktur Pendidikan Madinatul Qur'an. Menanggapi perkembangan lingkungan eksternal pondok pesantren, baik perkembangan ekonomi, pasar, teknologi, trend sosial, maupun lingkungan sosial, pihak manajemen yayasan juga terus melakukan inovasi. Semua sumber daya yang dimiliki, baik berupa finansial, sarana fisik, SDM, dan teknologi serta sistem pengelolaan seiring berjalan terus dievaluasi dan diperbaiki.

Kompetensi manajerial sebagai kapabilitas pimpinan dalam memberikan tujuan organisasi, menanamkan visi, dan memberdayakan anggotanya untuk merealisasikan visi, menjadi kasus serupa dengan korporasi pada umumnya. Dalam (Kusmiati \& Rahadi, 2020), yang dikemukakan Lado bahwa kompetensi berbasis input meliputi sumber daya manusia, pengetahuan, ketrampilan dan kapabilitas yang memungkinkan terjadinya proses transformasi untuk menghasilkan barang dan jasa, serta memberi nilai. Juga terjadi di lembaga pondok pesantren. Kompetensi yang diakui biasanya mampu memberi benefit bagi lingkungan. Kompetensi berbasis output memenuhi segala aset strategis intangible yang berbasis aneka ragam pengetahuan seperti citra pondok pesantren, dan trust masyarakat.

Penjelasan ini didalami pula oleh peneliti untuk lebih menggali keunggulan kompetitif yang telah dideskripsikan oleh Bapak Direktur Pendidikan Madinatul Qur'an. Yang lebih menarik tentunya bagaimana perencanaan dan strategi yang dirancang pihak manajemen pondok pesantren untuk mencapai apa yang telah mereka konsepkan tersebut. Pertanyaan inilah yang kemudian mendorong semacam adanya hipotesis kerja untuk memilih topik "Perencanaan dan Strategi Komunikasi dalam Meningkatkan Adaptifitas Sumberdaya Manusia dan Keunggulan Kompetitif Lembaga" dalam artikel jurnal ini.

Pemilihan topik tersebut juga terkait dengan prestasi yang berhasil diraih oleh
Pondok Pesantren Tahfizh Madinatul Qur'an. Tingkat lokal, a) dinobatkan sebagai "Sekolah Sehat" sewilayah Kota Depok; b) dinobatkan sebagai "Pesantren Paling Ramah Anak" seKota Depok; c) Juara 1 kejuaraan Pencak Silat sewilayah Jabodetabek; d) berhasil menjadi Juara 1 MHQ (Musabaqah Hifzhil Qur'an) sewilayah Jabodetabek. Tingkat nasional, berhasil menjuarai lomba Pidato Bahasa Arab (Juara 2 Nasional Klasifikasi Pesantren Modern). Tingkat internasional, penyelenggaraan pendidikan di Madinatul Qur'an berhasil menarik hati Asosiasi Muslim Belanda, untuk dijadikan pilot project perencanaan dan strategi komunikasi strategis pada pendidikan Islam di Belanda.

Sisi menarik lain adalah trust masyarakat. Biaya boarding di pondok pesantren ini sebenarnya cukup mahal dibanding sebagian pondok pesantren sejenis. Dengan biaya pokok operasional pendidikan Rp 2.500 .000 (dua juta lima ratus ribu rupiah) perbulan, pondok pesantren ini selalu dipenuhi pendaftar setiap kali perekrutan santri baru dibuka. Bahkan, hampir satu tahun sebelum dibuka pendaftaran sudah ada yang "memesan", dan paling tidak satu semester sebelum tahun ajaran baru, kuota santri peserta belajar sudah penuh.

Untuk itu, hal-hal yang berkaitan dengan aspek perencaanaan dan strategi, seperti perencanaan, implementasi, pengendalian, ataupun evaluasi dan strategi komunikasi akan menjadi tahapan-tahapan analisis yang akan peneliti kemukakan. Proses ini yang tentunya akan menjadi pedoman kerja penelitian ini berdasarkan kata-kata kunci: strategi komunikasi, perencanaan sumber daya manusia dan keunggulan kompetitif.

Oleh karena dalam kegiatan perencanaan akan terdapat aspek monitoring, evaluasi dan pengendalian (MEP) dari program komunikasi strategis, maka pedoman kerja penelitian juga mempertimbangkan sistematika MEP tersebut dalam tahapan pembahasan. Tentunya sebagai unsur strategi komunikasi yang sedang dilaksanakan, MEP ini juga peneliti anggap sebagai hal menarik berkaitan dengan antisipasi stigma publik tentang kekhawatiran isu 
pendidikan pondok pesantren yang terdapat potensi radikal. Tentunya, MEP akan diikuti dengan bentuk bentuk upaya pengawasan (supervision).

Dalam hal keunggulan kompetitif, dengan persaingan program yang terus meningkat dan beragam, menjadi tantangan bagi strategi dan perencanaan komunikasi yang tidak mungkin terelakkan. Dengan target memiliki keunggulan kompetitif pula motivasi kinerja akan meyakinkan para pengelola dan pelaku di dalamnya.

Sebagai kajian literatur dalam penelitian ini digunakan penelitian pertama dari

(Mahanani \& Christanti, 2020), Tujuan penelitian adalah untuk mengetahui strategi komunikasi organisasi yang dilakukan oleh Fungsi HSSE (Health, Safety, Security and Environment) PT Pertamina Patra Niaga dalam mencegah segala resiko yang mungkin terjadi dan berpotensi mempengaruhi citra perusahaan. Hasil penelitian ini memperlihatkan bahwa Fungsi HSSE PT Pertamina Patra Niaga merupakan sebuah fungsi yang penting dalam menjaga citra perusahaan. Fungsi ini terbentuk atas pentingnya aspek keselamatan pada perusahaan yang padat akan resiko (high risk). Dalam menjalankan tugas pokok dan fungsi HSSE, fungsi ini melakukan berbagai strategi komunikasi dalam lingkup organisasi untuk membudayakan aspek keselamatan pada seluruh stakeholder di perusahaan dengan tujuan yaitu menjaga citra perusahan.

Penelitian kedua (Kasmawati, 2018), dari hasil penelitian yang dikemukan terkait implementasi pemberdayaan SDM, yang mencakup: dimensi pemberdayaan yang telah diimplementasikan dengan baik adalah perlindungan (protecting), dimensi yang sedang dilakukan perlunya peningkatan adalah penguatan (empowering), pemungkinan (enabling), dan penyokongan (supporting), dimensi yang paling lemah serta perlu mendapat perhatian ekstra adalah dimensi pemeliharaan (fostering).

Ketiga state of the art diatas dijadikan pijakan peneliti sebagai upaya mengeksplorasi program strategi komunikasi kaitannya dengan pemetaan SDM (sumber daya manusia) yang sangat adaptif terhadap penguatan kelembagaan. Terdapat beberapa perbedaan terhadap penelitian yang telah terlaksana oleh peneliti. Pertama, masih sangatlah jarang bentuk-bentuk penelitian strategi komunikasi organisasi yang bersinggungan dengan SDM khususnya fungsi Pendidikan pada Lembaga Pesantren. Kedua, penelitian ini dirasakan peneliti bersifat unik dan baru disebabkan belum adaya penelitian sejenis yang membahas perencanaan terhadap adaptifitas SDM dan keunggulan lembaga secara kompetitif.

Menurut Donelly dalam (Doembana, I., Rahmat, A., \& Farhan, 2017) strategi hendaknya mampu memberi informasi kepada public yang sekaligus mudah dipahami oleh setiap anggota manajemen puncak dan setiap karyawan organisasi. Ada enam informasi yang tidak boleh dilupakan dalam suatu strategi, yaitu: (What). Apa, apa yang akan dilakukan; (Why) Mengapa demikian, suatu uraian tentang alasan yang dipakai dalam menentukan apa diatas; (How). siapa yang akan bertanggung jawab untuk atau mengoperasionalkan strategi; (How much). Berapa banyak biaya yang harus dikeluarkan untuk menyukseskan strategi; (How Long). Berapa lama waktu yang diperlukan untuk operasionalisasi strategi tersebut; (Out Put). Hasil apa yang diperoleh dari suatu strategi. Sedangkan dalam (Sukma \& Pranawukir, 2020) terdapat 2 (dua) strategi push dan strategi pull. Makna push merupakan dorongan agar ada efek pacu, yang targetnya tidak hanya kapasitas tetapi juga daya saing, sedangkan pass sebagai upaya mempengaruhi atau menciptakan opini public.

Sejatinya strategi adalah "suatu perencanaan untuk mengetahui apa yang harus dilakukan suatu organisasi dalam bisnis, bagaimana menyelesaikannya, dan bagaimana hal itu dapat menarik dan memuaskan pelanggan dalam rangka mencapai suatu tujuan." Strategi komunikasi penitikberatan sumber daya manusia sangat berhubungan erat dengan peningkatan kemampuan intelektual yang diperlukan untuk melaksanakan pekerjaan yang lebih baik, komunikasi strategis sumber 
daya manusia berpihak pada fakta bahwa setiap tenaga kerja membutuhkan pengetahuan, keahlian, dan keterampilan yang lebih baik. Komunikasi strategis lebih terfokus pada kebutuhan jangka panjang dan hasilnya hanya dapat diukur dalam waktu jangka panjang.Adapun fungsi MSDM adalah: perencanaan, pengorganisasian, pengarahan, pengendalian, pengadaan. (Purnama Dewi, Desilia and Harjoyo, 2019)

Sedangkan Strategi Komunikasi dalam Manajemen Sumber Daya Manusia mengacu pada kebijakan dan praktik yang terlibat dalam melaksanakan aspek posisi manajemen, termasuk perencanaan sumberdaya manusia, pekerjaan analisis, rekrutmen, seleksi, orientasi, kompensasi, penilaian kinerja, pelatihan dan hubungan pembangunan, serta tenaga kerja (Dessler, 2007) dalam (Sugiharjo \& Rustinah, 2017)

Pesantren adalah kompleks dengan tempat yang umumnya terpisah dari kehidupan di sekitarnya. Pesantren adalah bentuk lingkungan masyarakat yang unik dan memiliki sistem kehidupan positif yang memiliki karakteristik sendiri sebagai lembaga pendidikan Islam yang dilengkapi dengan norma dan kebiasaannya sendiri. Sistem pendidikan pesantren dapat dipertahankan relatif murah semua kebutuhan belajar mengajar disediakan oleh anggota pesantren bersama dengan dukungan dari masyarakat sekitar." Pesantren yang diakui sebagai cikal bakal pendidikan nasional dan diakui survive sejak zaman penjajahan, ternyata menyimpan seribu pertanyaan kenapa hal tersebut bisa terjadi? Kelangsungan hidup suatu pesantren yang sangat bergantung kepada "daya tarik" tokoh sentral (kyai atau guru) yang memimpin, meneruskan atau mewarisinya. (Faisol, 2017)

Maka figur pemimpin pesantren menjadi rukun utama jika ingin kehidupan pesantren menjadi abadi. Kepemimpinan seorang kyai (top leader) menjadi penting karena dia adalah satu-satunya orang yang memiliki wewenang. Sebagaimana disebutkan di atas bahwa kelangsungan hidup suatu pesantren sangat bergantung kepada "daya tarik" tokoh sentral (kyai atau guru) yang memimpin, meneruskan atau mewarisinya.

Adapun tujuan umum penelitian adalah ingin mengetahui gambaran perencanaan strategi komunikasi dalam mencapai keunggulan kompetitif, khususnya di pondok pesantren. Sedangkan tujuan khususnya adalah mengetahui perencanaan komunikasi strategis dalam meningkatkan keunggulan lembaga

Dari rangkaian definisi diatas menjadi fokus peneliti adalah keunikan Madinatul Quran yang modern dengan melestarikan tradisi klasik serta elaborasi pendidikan umum serta memunculkan keunggulan. Dibandingkan pondok pesantren sejenis, program pendidikan Madinatul Qur'an lebih pada antisipasi jauh ke depan, yakni prospek lulusan setelah 3 (tiga) atau 5(lima) tahun menamatkan proses pendidikan (outcome base education), sehingga rumusan masalahnya: "Bagaimana perencanaan dan strategi komunikasi dalam meningkatkan adaptifitas sumberdaya manusia Pondok Pesantren Tahfizh Modern "Madinatul Qur'an" Depok?" dan "Tahap-tahap perencanaan dan strategi komunikasi dalam meningkatkan keunggulan kompetitif lembaga?"

\section{METODOLOGI PENELITIAN}

Tipe penelitian ini adalah deskriptif kualitatif (J.R. Raco, 2018) Faktor lain yang berpengaruh terhadap munculnya dan berkembangnya metode kualitatif adalah ideologi, politik, ekonomi dan gerakan sosial kemasyarakatan. Menurut (Moleong, 2017), penelitian kualitatif bermaksud untuk memahami fenomena tentang apa yang dialami oleh subjek penelitian, misalnya perilaku, persepsi, motivasi, tindakan, dan lain-lain, secara holistik, pada suatu konteks khusus yang alamiah dan dengan memanfaatkan berbagai metode alamiah. Penelitian deskriptif hanya memaparkan situasinya atau peristiwa penelitian, tidak mencari atau menjelaskan hubungan, tidak menguji hipotesis atau membuat prediksi. Peneliti bertindak hanya sebagai pengamat, hanya membuat kategori perilaku, mengamati dan mencatat dalam buku 
observasinya Rachmat (2008) dalam (Setiawan \& Fithrah, 2018).

Tempat penelitian adalah pondok pesantren Madinatul Qur'an wilayah Cilodong Depok serta cabang-cabangnya yang lokasinya relatif masih dalam wilayah Depok-Jakarta. Kampus Madinah berada dalam teritorial Depok, tetapi kampus Mekkah berada dalam teritorial Jakarta. Penelitian sudah diawali secara konsisten pada awal bulan April hingga Agustus 2020. Adapun penelitian diakhiri sampai pada pencapaian "data jenuh" sesuai aspek kedalaman penelitian yang menjadi syarat kecukupan penelitian. Subjek penelitian adalah para pejabat struktural dan pengajar di pondok pesantren Madinatul Quran sebagai narasumber. Hal ini ditempuh melalui teknik purposive dan snowball dari narasumber utama.

Sedangkan data adalah transkrip hasil observasi dan wawancara, baik secara elektronik (mengingat suasana pandemi Covid19) maupun manual (peneliti berkunjung secara langsung ke pondok pesantren). Selain itu, triangulasi data juga dilakukan melalui kepustakaan (berkunjung ke Perpustakaan Madinatul Qur'an), melihar buku arsip, laporan kegiatan pelaksanaan dan penyelenggaraan sumber daya manusia, serta dokumentasi. Adapun sumber data utama adalah hasil wawancara dengan segenap pihak manajemen pondok pesantren

\section{HASIL DAN PEMBAHASAN}

\section{Tahapan Komunikasi Organisasi Untuk Meningkatkan Sumber Daya Manusia Adaptif Perencanaan}

Pada tahap perencanaan manajemen Pondok Pesantren Madinatul Qur'an membagi dua kegiatan pembelajaran pondok pesantren dalam 3 (tiga) fungsi, yakni saintifik, character and capacity building dan Mahad Aly. Gedung MQ-1 (kampus Madinah) khusus untuk bidang keilmuan umum, sesuai pendidikan yang telah diprogramkan oleh pemerintah. Gedung MQ-2 (kampus Madinah) khusus untuk character and capacity building, di dalamnya terdapat kegiatan pembinaan e-preneurship, kemampuan berorganisasi, manajemen perubahan, peluang dan tantangan digitalisasi, boarding dan kegiatan sorogan, tasmik, bandongan dan kajian kitab kuning. (mesjid berada pada area ini). Gedung MQ-3 (kampus Mekah) khusus untuk Mahad Aly, sebagai kegiatan mahasantri selama dua tahun, yang menjadi sumberdaya pengajar tahfidz di lingkungan MQ sendiri ataupun memenuhi kebutuhan pengajar tahfidz di luar MQ.

Berdasarkan pemetaan di atas, maka dari sisi perencanaan, strategi komunikasi pada SDM pondok pesantren Madinatul Qurán mencoba mengakomodasi beberapa elemen yang sebenarnya pada masa-masa sebelumnya sangat tidak populer. MQ tidak saja berusaha mencoba mengadaptasi pendidikan formal dan pendidikan pondok pesantren, tetapi juga tuntutan SDM yang mampu berperan dalam dunia kreatif, utamanya kreatif dalam memanfaatkan media baru. Konten $e$ preneurship yang pada mulanya hanya terakomodasi pada lembaga-lembaga eksklusif justru diinternalisasi oleh pondok pesantren sebagai bagian yang tidak terpisahkan dari dunia "mengaji". Justru dunia "mengaji" menjadi potensi komoditas yang sangat konstruktif dalam e-preneurship.

\section{Pelaksanaan}

Pada tahap pelaksananan manajemen Pondok Pesantren Madinatul Qur'an melakukan hal sebagai berikut: Program Peningkatan Kemampuan Public Speaking. Dalam misi syiar Islam tentu dibutuhkan kemauan dan kemampuan secara personal untuk berbicara di depan khalayak dengan etika islamiah sebagaimana tuntunan Alqur'an dan Hadidz. Untuk itu seorang pendakwah, dalam konteks antarpribadi maupun di depan publik harus dibekali terlebih dahulu dengan ketrampilan terkait. Kemampuan public speaking tidak hanya berpengaruh pada keberhasilan dakwah, tetapi citra Islam itu sendiri. Mengingat komunikasi publik kini banyak dibutuhkan oleh seluruh masyarakat, karena mobilitas masyarakat yang sangat 
intensif terlibat dalam forum-forum publik, utamanya kajian-kajian Islam. (berdasarkan hasil wawancara pimpinan dan pengurus harian )

Di sisi lain adalah persoalan bisnis. Dalam bisnis tidaklah mungkin dilakukan dengan "membisu". Produk tidak akan "berbicara" tanpa adanya pesan personal dari penjual ke pembeli, apalagi produk-produk lingkar kecil yang masih membutuhkan sosialisasi dan introduksi. Oleh karena itu, kemampuan public speaking menjadi modal inti dari kompetensi bisnis. Pribadi yang terampil berbicara di depan umum, akan lebih dihargai, lebih dibutuhkan lingkungan dan berkesempatan untuk lebih sukses dalam mendapatkan peluang sosial, baik itu peluang pengakuan maupun kepercayaan diri yang akan meningkatkan munculnya potensi-potensi lain baik direncanakan maupun tidak. (berdasarkan hasil wawancara pimpinan dan pengurus harian )

Adapun pemanfaatan teknologi dari kemampuan sebelum diberikan pembekalan dengan kondisi sesudah diberikan pembekalan. Hal ini menyangkut performansi pribadi, peningkatan peran dan kemampuan komunikasi antarpribadi, kelompok dan organisatoris serta publik. Di samping itu juga wawasan dalam pemanfaatan media dan inisiatif aktualisasi diri dalam memanfaatkan media untuk menunjang kegiatan dakwah, bisnis dan aktualisasi diri.

Adapun proses pelaksanaannya sebagai berikut: pelatihan terbagi dalam 4 (empat) sesi. Setiap sesi diikuti oleh seluruh mahasantri dan santri yang hadir, biasanya juga dihadiri oleh mitra pondok pesantren, yakni kalangan akademisi dan praktisi dari eksternal. Setiap sesi dilaksanakan selama 3 (tiga) jam waktu efektif, terdiri dari 1(satu) jam pembekalan materi secara umum (diikuti seluruh santri), selanjutnya 2 (dua) jam terakhir jamaah akan dibagi dalam 3 (tiga) kelompok sesuai target capaian, yakni program trainer, enterpreneur atau leader. Dapat dikatakan tahap pelaksanaan, yang terdiri dari :

\section{Pengabdian kepada Masyarakat}

Para santri terpilih di tingkat Mahad Aly juga diprogramkan dalam terapan sosial kemasyarakatan, yakni langsung membina majelis taklim. Berdasarkan informasi dari pihak pondok, sebagai induk pembina, pihak yang ingin berpartisipasi dalam kegiatan majelis ta'lim dapat dikelompokkan dalam 3(tiga) kategori, yakni jamaah yang sudah bekerja secara formal, jamaah yang kerjanya berdagang dan jamaah aktif di berbagai organisasi kemasyarakatan. Kelompok yang pertama, tentunya banyak terlibat dalam kegiatan di institusi atau instansinya dalam berbagai kegiatan yang melibatkan kemampuan publik. Kelompok kedua, banyak terlibat dengan pemasaran dan trust konsumen. Sangat jelas kelompok ini membutuhkan kemampuan komunikasi bisnis. Kelompok terakhir adalah para pemuda yang aktif di berbagai kegiatan organisasi, sehingga kemampuan public speaking sangat berguna bagi mereka untuk meningkatkan peran personal mereka dalam berbagai kesempatan, apalagi jika mengingat usia mereka yang masih sangat produtif dan kontributif bagi keluarga, masyarakat dan organisasi mereka. (berdasarkan hasil wawancara)

\section{Peningkatan Kemampuan Manajerial dan Optimalisasi Bisnis}

Koperasi merupakan soko guru ekonomi masyarakat. Demikian seperti sudah lama dikenal secara luas. Di seluruh organisasi, koperasi merupakan perkumpulan yang konstruktif dan kontributif bagi kebersamaan dan kesejahteraan karyawan. Demikian pula di pondok pesantren tempat pengabdian, koperasi karyawan Pondok Pesantren Tahfidz Madinatul Qur'an yang berlokasi di Jalan Al Hidayah 20, RT 05/02, Kelurahan Jatimulya Kecamatan Cilodong Kota Depok Jawa Barat. Di dalamnya juga ada koperasi. Sebagai pondok pesantren yang tengah berkembang, maka koperasipun masih belum terorganisir dengan rapi. Menurut penjelasan Bapak Direktur Pendidikan Pondok Pesantren, hal ini dikarenakan aspek SDM yang memang kurang memadahi. Para pengelola 
koperasi masih sangat terbatas, dan memang belum ada niat untuk memperbesar, karena santri yang ada masih didominasi oleh kaum laki-laki.

Namun demikian, Bapak Direktur mengatakan bahwa koperasi juga menjadi salah satu praktik bisnis organisatoris yang sangat berguna bagi para santri. Memang, selama ini dari sisi manajerial, koperasi masih dikelola berdasarkan manajemen toko biasa, yang lebih banyak didominasi oleh kegiatan jual beli. Kegiatan simpan pinjam masih sebatas sukarela, belum ada studi kelayakan seberapa idealnya simpanan wajib dan sukarelanya. Jadi secara umum, ditinjau dari aspek manajerial, keberadaan koperasi belum mencapai sebagaimana kondisi idealnya. Pihak pondok menghendaki kemajuan kegiatan koperasi bukan hanya sebatas jual beli, tetapi mencapai bisnis yang lebih luas. Sayangnya bisnis yang dimaksud diharapkan tidak bersangkut paut dengan riba.

Pihak pondok menghendaki kemajuan kegiatan koperasi bukan hanya sebatas jual beli, tetapi mencapai bisnis yang lebih luas. Sayangnya bisnis yang dimaksud diharapkan tidak bersangkut paut dengan riba. Oleh karena itu melalui kegiatan peningkatan ini, pihak pondok pesantren menginginkan adanya terobosan-terobosan pengelolaan "koperasi" yang baru yang pengelolaan manajerialnya tidak seperti koperasi pada umumnya, dalam arti tidak ada anggota dan RAT (Rapat Anggota Tahunan).

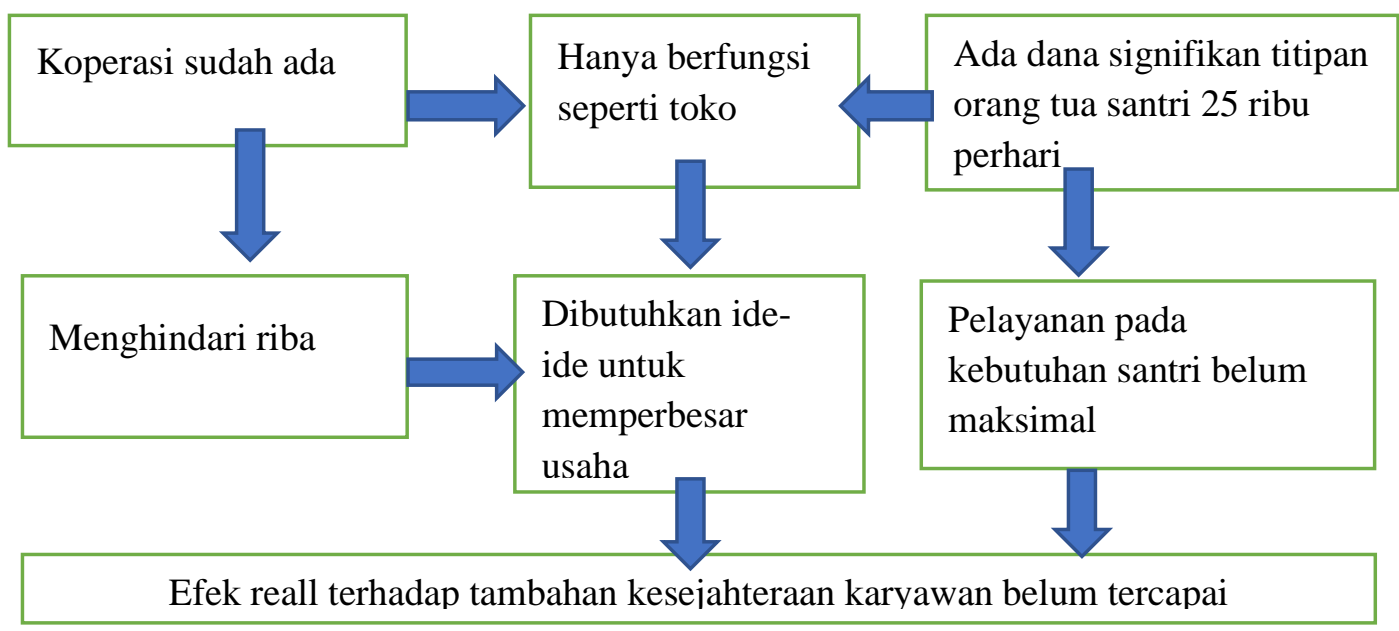

Bagan 1. Pengelolaan Koperasi MQ

(sumber: disusun ulang oleh Peneliti, 2021)

\section{Peningkatan Perencanaan dan Strategi Komunikasi Tahfidz}

Jika dilihat dari sisi sosial kemasyarakatan, seorang tahfidz atau lulusan pondok pesantren memiliki status sosial yang tinggi, karena banyak sekali identitas yang kemudian melekat pada diri mereka: ustadz, pendakwah, mubalig, tahfidz sampai pada karakter beretika dan bermoral tinggi. Di satu sisi, hal ini merupakan hal positif, tetapi melekat pula tanggung jawab yang tidak ringan. 


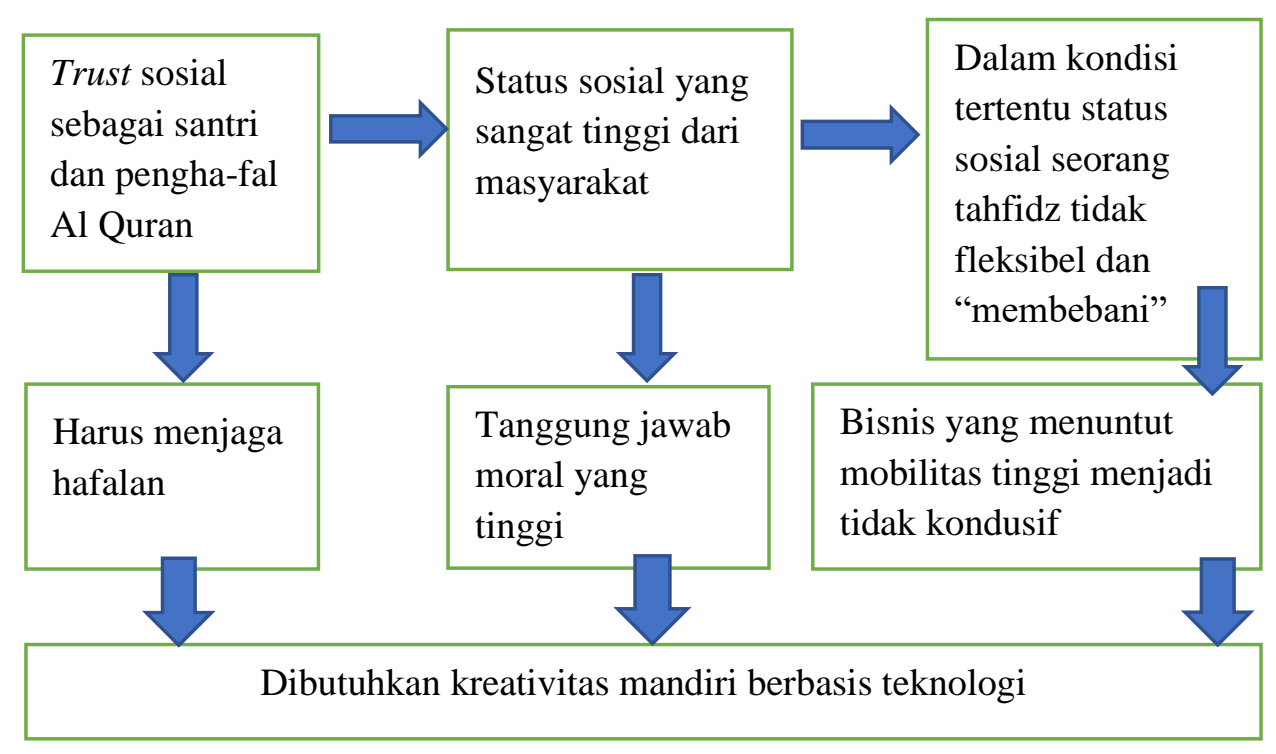

Bagan 2. Tuntutan Kreativitas Penggunaan Teknologi

(sumber: disusun ulang oleh Peneliti, 2021)

\section{Peningkatan Pemahaman Strategi Pemasaran Santri}

Target dari strategi komunikasi dalam strategis kemampuan jenis ini adalah adanya produksi air kemasan yang dikelola sepenuhnya oleh para santri. Pondok pesantren ini memiliki usaha air minum kemasan dengan branding nama pondok. Sayangnya, sampai penelitian ini dilakukan, sebagai hasil observasi ke lokasi penelitian, usaha tersebut tidak berkembang, karena kalah bersaing dengan produk-produk lain yang sudah ada

Berdasarkan penjelasan Direktur Pendidikan Pondok Pesantren, hal ini terutama disebabkan oleh faktor SDM santri dan pengajar yang tidak memiliki kemampuan manajerial pemasaran dan penjualan yang memadai. Alhasil, konsumsi atau distribusi penjualan hanya sampai internal pondok pesantren saja. Oleh karena itu, pihak pondok menginginkan adanya pembinaan manajerial dan strategi pemasaran serta penjualan, agar ke depannya tidak saja memenuhi kebutuhan internal pondok, tetapi juga menjadi usaha santri dalam bentuk industri pondok pesantren.

\section{Perencanaan dan Strategi Komunikasi MQ Untuk Meningkatkan Keunggulan Kompetitif}

\section{Monitoring sebagai Outcome Base Education versi Madinatul Qur'an}

Pondok Pesantren Modern - Tahfidz Madinatul Qur'an berlokasi di Jl. Al Hidayah 20, RT 05/02, Kel. Jatimulya Kec Cilodong Kota Depok Jawa Barat. Saat ini pondok tersebut hanya menerima santri pria di tingkat SMP dan SMA. Di samping itu pondok juga menyelenggarakan pendidikan Ma'had Aly (mahasantri) setingkat Diploma II yang seluruh pembiayaannya gratis.

Fenomena pondok pesantren memang mengalami perubahan signifikan. Jika masa lampau, pondok pesantren merupakan "sekolah" tradisional bagi kalangan ekonomi menengah ke bawah, tetapi kini pondok pesantren justru banyak dimasuki oleh kalangan ekonomi menengah ke atas. Tidaklah mengherankan jika pondok pesantren kini semakin bernuansa eksklusif. Terlebih lagi jika dikaitkan dengan kemampuan ganda lulusan pondok pesantren, yakni Bahasa Arab, Baca Alqur'an, Hafalan Alqur'an serta pendidikan umum. 


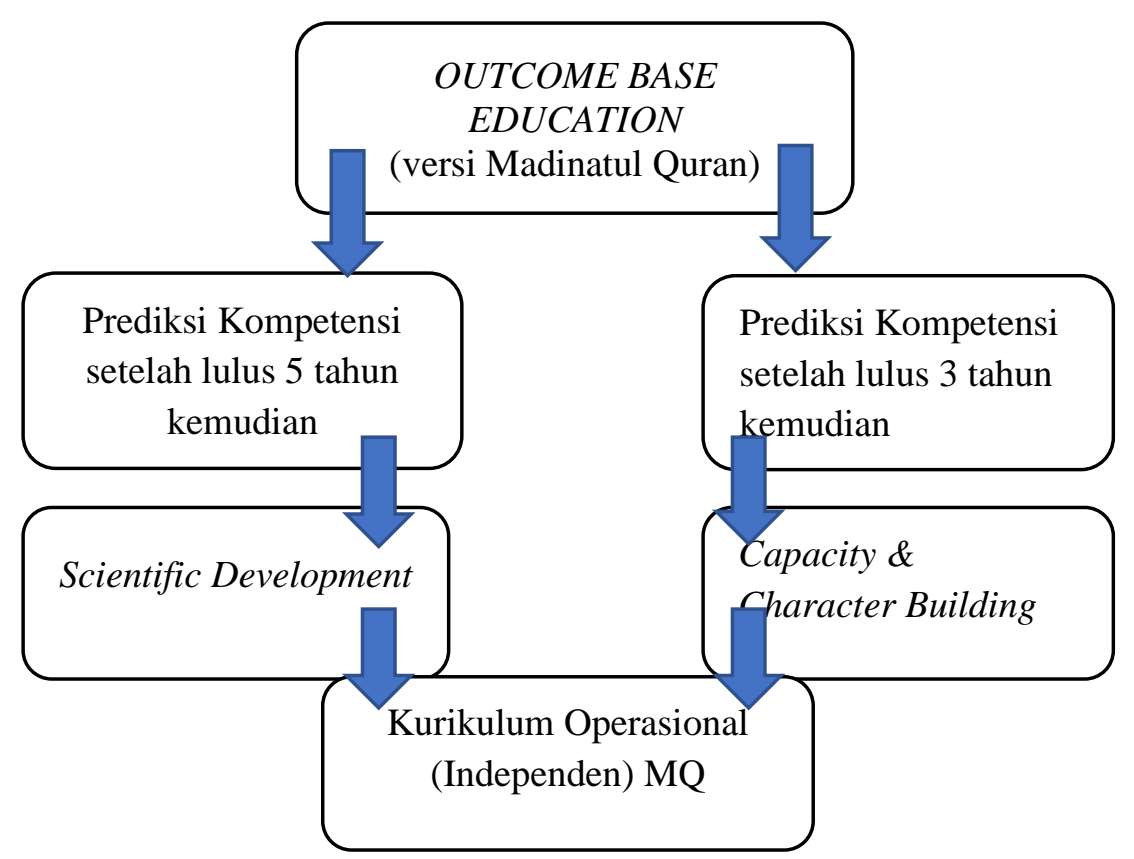

Bagan 3. Model OBE (Outcome Base Education) versi MQ

\section{Tantangan Outcome SDM Lulusan Pondok Pesantren}

Para santri tahfidz, yang memang dikondisikan untuk tidak berinteraksi secara bebas (tanpa bebas) berinteraksi dengan masyarakat luas, di satu sisi sebagai jalan untuk konsentrasi, di sisi lain menjadi tantangan di saat mereka harus kembali ke masyarakat. Sebagai pola pendidikan yang memfokuskan diri sebagai penghafal Kitab Suci Alqur'an, "isolasi" dalam kurun waktu tertentu memang sangat diperlukan. Bukan persoalan mudah mengondisikan mereka secara disiplin untuk sampai "lulus", apalagi jika target hafalan adalah 30 juz dengan detil kaidah tajwid dan segala tata bahasa khas Kitab Suci Alqur'an.

Jika dilihat dari sisi sosial kemasyarakatan, seorang tahfidz atau lulusan pondok pesantren memiliki status sosial yang tinggi, karena banyak sekali identitas atau jabatan yang kemudian melekat pada diri mereka: ustadz, pendakwah, mubalig, tahfidz sampai pada karakter beretika dan bermoral tinggi. Di satu sisi hal ini merupakan hal positif, tetapi melekat pula tanggung jawab yang tidak ringan.

\section{Evaluasi}

Dalam tahapan monitoring, pihak manajemen MQ memberlakukan unsur-unsur kebijaksanaan sebagai berikut: Tidak deskriminatif berdasarkan suku, ras, agama, golongan, warna kulit dalam rekrutmen dan seleksi, penempatan, pelatihan, promosi, kompensasi, dan lain-lain.

Memberi peluang yang sama pada siapa saja untuk berprestasi dan mendapatkan insentif atas hasil pengabdiannya. Program-program yang dibuat dilaksanakan semata-mata untuk membantu SDM sasaran demi meningkatkan kemampuan kerja (kinerja) dengan tujuan akhir meningkatkan kontribusi masing-masing sesuai tujuan pondok pesantren

Menyalurkan kreativitas, inisiatif dan aspirasi.Menyediakan informasi/data mengenai hal-hal yang berkaitan dengan komunikasi strategis capacity building dan character building.

\section{Pengendalian}

Perubahan tuntutan, kebutuhan dan tantangan yang sangat cepat, memaksa pondok pesantren untuk menyesuaikan diri dalam 
komteks komunikasi organisasi. Perubahan tersebut dengan sendirinya telah menggeser fungsi-fungsi manajemen sumber daya manusia yang selama ini hanya dianggap sebagai kegiatan administrasi, yang berkaitan dengan perekrutan, staffing, coordinating yang dilakukan oleh personalia. Saat ini manajemen SDM yang diaplikasikan oleh Madinatul Qur'an tentu sudah berubah ke arah fungsi organisasi yang terintegrasi dengan seluruh fungsi lainnya di dalam organisasi, untuk bersama-sama mencapai sasaran yang sudah ditetapkan serta memiliki fungsi perencanaan yang sangat strategis dalam organisasi. Oleh karenanya Manajemen SDM mempunyai kewajiban untuk memahami perubahan yang semakin komplek, mengantisipasi perubahan teknologi, dan memahami dimensi sosial yang mulai memasuki bisnis akibat informasi yang berkembang cepat. Perubahan paradigma dari Manajemen SDM tersebut telah memberikan fokus yang berbeda bagi Madinatul Qur'an dalam melaksanakan fungsinya di dalam organisasi yang memiliki identitas penyelenggara pendidikan modern. Unsur modern inilah yang menjadi target pengendalian, yakni tetap modern yang tidak menghilangkan tradisi klasik para pendahulu, yakni berpedoman pada Alqur'an, hadidz, ijma dan qiyas, sebagai tradisi ahlussunnah wal jama'ah.

\section{Tahapan Pengawasan}

Dalam menjawab pertanyaan-pertanyaan peneliti mengenai tahapan pengawasan, peneliti mendapatkan hal-hal yang berkaitan dengan tahapan pengawasan versi Madinatul Qur'an sebagai berikut: sumberdaya yang menjadi core business dari sumberdaya manusia Madinatul Qur'an adalah para ustadz lulusan Mahad Aly. "Menurut saya kalau inti SDM ya menurut saya Mahad Aly". Sumberdaya adalah manusia yang sangat tidak identik dengan mesin, sehingga pendekatan yang digunakan adalah human relations, sebagai praktik pengelolaan SDM mayor dan human resources dalam praktik minor.

\section{Perencanaan dan Strategi Komunikasi Organisasi Untuk Meningkatkan Keunggulan Lembaga MQ melalui}

\section{Pengadaan Sumber Daya}

Recruitment disini diartikan pengadaan, yaitu suatu proses kegiatan mengisi formasi struktur, mulai dari perencanaan, pengumuman, pelamaran, penyaringan sampai dengan pengangkatan dan penempatan. Pengadaan yang dimaksud bermakna lebih luas, karena pengadaan dapat merupakan salah satu upaya dari pemanfaatan. Jadi, pengadaan disini adalah upaya penemuan calon dari dalam organisasi maupun dari luar untuk mengisi jabatan yang memerlukan SDM berkualitas. Dalam pelaksanaannya bisa berupa recruitment from outside dan recruitment from within.

Adapun Madinatul Qur'an cenderung melakukan versi recruitment from within dengan memaksimalkan lulusan Mahad Ali sebagai tenaga fungsional mereka. Sampai sejauh ini, sesuai klaim Direktur Pendidikan tidak ada istilah gagal dari hasil prerekrutan lulusan Mahad Aly.

Sehingga struktur organisasi MQ dapat disimpulkan adanya pola hubungan, adanya pola kerja diantara anggota organisasi, terkait pembagian tugas, wewenang yang kesemuanyadapat direncakan diorganisasikam dalam suatu penetapan dalam struktur organisasi yang ada dalam pesantren MQ.

\section{Pemeliharaan Sumber Daya Manusia}

Manusia mempunyai kepentingan, kebutuhan, keinginan, kehendak dan kemampuan, dan manusia juga mempunyai harga diri. Hal-hal tersebut di atas juga menjadi perhatian pimpinan dalam manajemen SDM. Pihak manajemen Madinatul Qur'an juga menyadari bahwa pemeliharaan SDM perlu diimbangi dengan sistem insentif (incentive system), baik yang berupa finansial, seperti gaji, tunjangan, maupun yang bersifat material seperti: fasilitas perumahan, pengobatan, dan lain-lain yang terkait. Di samping itu juga diadakan insentif immaterial seperti: kesempatan untuk pendidikan dan pelatihan. 


\section{Strategi Komunikasi Pada Sumber Daya Manusia}

Strategi komunikasi pada sisi ini dilaksanakan melalui pendidikan dan pelatihan yang berkesinambungan. Pendidikan dan pelatihan merupakan upaya untuk pengembangaan SDM, terutama untuk komunikasi strategis kemampuan intelektual dan kepribadian (capacity and character building). Pendidikan berkaitan dengan mempersiapkan calon tenaga yang digunakan (di program Ma'had Aly), sedangkan pelatihan lebih berkaitan dengan peningkatan kemampuan atau keterampilan pekerja yang sudah menduduki suatu tugas tertentu.

Perencanaan dan strategi komunikasi SDM Madinatul Qur'an hasil Ma'had Aly akan terus difasilitasi untuk melanjutkan jenjang pendidikan lebih tinggi sesuai dengan tuntutan masyarakat. Di samping itu, dalam perencanaan strategis pondok pesantren, Ma'had Aly yang selama ini masih diselenggarakan secara mandiri dengan kurikulum versi sendiri tanpa aspek legalitas formal dari Dinas Pendidikan terkait akan dikelola dan dinaikkan statusnya menjadi jenjang pendidikan S1 sebagaimana Ma'had Aly yang sudah terdaftar di Departemen Agama. Sebelum rencana ini terwujud, lulusan Ma'had Aly yang sudah menjadi tenaga fungsional difasilitasi untuk kuliah di berbagai Perguruan Tinggi sesuai dengan bidang peminatan dan kemampuan mereka.

\section{SIMPULAN}

Strategi komunikasi dalam meningkatkan sumber daya manusia adaptif dan keunggulan kompetitif di Pondok Pesantren Tahfizh Madinatul Qur'an Kota Depok, paling dominan menggunakan Strategi Agresif. Hal ini menandakan bahwa perkembangan institusi sangat pesat dan berada pada posisi kompetitif yang kuat, sehingga sangat prospektif. Oleh karena itu pertumbuhan organisasi juga berpotensi tinggi, sehingga pada posisi ini juga dapat disebut dalam terapan growth strategy. Strategi ini dihasilkan dari pemikiran yang logis, analitis serta konseptis terhadap hal-hal prioritas (dalam jangka panjang, pendek maupun mendesak), untuk dijadikan acuan dalam menetapkan langkah, tindakan, kiat, dan taktik. Semua itu dilakukan secara terpadu, dalam upaya peningkatan, sesuai dengan tujuan, sasaran, dan hasil (output dan outcome). Adapun tahapan perencanaan komunikasi dalam meningkatkan sumberdaya manusia adaptif Madinatul Quran adalah sebagai berikut: perencanaan, perumusan strategi, pelaksanaan, MEP (Monitoring, Evaluasi dan Pengendalian), Evaluasi dan pengendalian program serta pengawasan.

Peneliti memfokuskan bahwa hasil kesimpulan bahwa strategi komunikasi strategis MQ berpusat dan menitikberatkan pada SDM. Dengan lulusan Ma'had Aly yang difasilitasi melanjutkan jenjang pendidikan formalnya, serta rencana pendirian kampus jenjang S1 (strata-1) demi melegalformalkan para lulusan Ma'had Aly.

\section{DAFTAR PUSTAKA}

Doembana, I., Rahmat, A., \& Farhan, M. (2017). Manajemen dan Strategi Komunikasi Pemasaran. Yogjakarta: Zahir Publishing.

Faisol, M. (2017). Peran Pondok Pesantren Dalam Membina Keberagamaan Santri. Al-Tanzim: Jurnal Manajemen Pendidikan Islam, 1(2), 37-51. https://doi.org/10.33650/altanzim.v1i2.112

Hasibuan, M. (2016). Manajemen Sumber Daya Manusia. Jakarta: PT. Bumi Aksara.

J.R. Raco. (2018). Metode Penelitian Kualitatif: Jenis, Karakteristik dan Keunggulannya. Jakarta: PT Gramedia Widisarana Indonesia.

Karnati, N. (2019). Komunikasi Organisasi Dalam Persfektif Manajemen Pendidikan. Banda Aceh: CV. Bunda Ratu.

Kasmawati, K. (2018). Sumber Daya Manusia Sebagai Sumber Keunggulan Kompetitif. Idaarah:Jurnal Manajemen Pendidikan, 2(2). $\quad$ https://doi.org/DOI: 
https://doi.org/10.24252/idaarah.v2i2.686 4

Kusmiati, L., \& Rahadi, D. R. (2020). Pengembangan Kompetensi Mahasiswa Di Masa Pandemic Covid-19. Manajemen Bisnis (JMB), 33(2), 92-101. https://ejournal.stieibbi.ac.id/index.php/j $\mathrm{mb} /$ article/view/138

Mahanani, F. P., \& Christanti, M. F. (2020). Strategi Komunikasi Organisasi Fungsi HSSE PT Pertamina Patra Niaga Dalam Menjaga Citra Perusahaan. Jurnal Pustaka Komunikasi, 3(1), 100-111.

Moleong, L. . (2017). Metode Penelitian Kualitatif. Bandung: PT. Remaja Rosdakarya.

Muammar. (2017). Nurcholish Madjid Dan Harun Nasution Serta Pengaruh Pemikiran Filsafatnya. Petita: Jurnal Kajian Ilmu Hukum Dan Syariah, 2(2), 211-227. https://doi.org/10.22373/petita.v2i2.74

Prasojo, Lantip Diat Mukminin, Amirul Mahmudah, F. N. (2017). Manajemen
Strategi Human Capital Dalam Pendidikan (1st ed.). Yogjakarta: UNY Press.

Purnama Dewi, Desilia and Harjoyo, H. (2019). Manajemen Sumber Daya Manusia. Tangerang Selatan: Unpam Press.

Setiawan, B., \& Fithrah, D. S. (2018). Kampanye Gerakan Indonesia Diet Kantong Plastik Dalam Membentuk Persepsi Masyarakat Bandung. Jurnal Manajemen Komunikasi, 2(2), 102-117.

Sugiharjo, R. J., \& Rustinah. (2017). Pengaruh Perencanaan Karir, Pengembangan Karir Karyawan Dan Terhadap Kinerja Karyawan Pada Jambuluwuk Puncak Resort. Ilmiah Manajemen Dan Bisnis, 3(03), 444-454.

Sukma, A. H., \& Pranawukir, I. (2020). Perencanaan dan Strategi Komunikasi Jaringan Franchise Warung Tegal Kharisma Bahari. WACANA: Jurnal Ilmiah Ilmu Komunikasi, 19(2), 274-284. https://journal.moestopo.ac.id/index.php/ wacana/article/view/1159 